Katarzyna KUKOWICZ-ŻARSKA ${ }^{1}$

Ateneum-Szkoła Wyższa w Gdańsku

\title{
O wartościowaniu i prawdzie w języku i tekście. Język narodowego socjalizmu w perspektywie językoznawczej i socjokulturowej
}

Summary

The subject of this publication are linguistic means of evaluation in the text and language, discussed on the basis of the German language of national socialism. The text and its role are perceived here through the prism of values in a universal context, and perhaps first of all through the prism of linguistic means of evaluation represented in it. As ratings are usually assigned to selected elements of reality created with language in order to not only reflect one's attitude towards these elements but also to implicitly effect a given or desired mental or physical reaction in the recipient of the language message, it should not be surprising that the language of national socialism is examined here in the linguistic and sociocultural perspective. The combination of national values important for the whole community and the official interpretation of truth and non-truth was a priority in the national socialist era. This article deals with the problem related to the interpretation of appropriate situations and their meanings considered as correct from the perspective of the language of values and issues related to manipulation and persuasion.

Keywords: text linguistics, evaluation, axiology, sociolinguistics, German language

\section{Wprowadzenie}

Niniejszy artykuł stanowi próbę naukowego spojrzenia na problem istoty wartościowania i prawdy w języku i tekście. Tematem niniejszej publikacji są językowe środki wartościowania $\mathrm{w}$ tekście, omawiane na podstawie języka niemieckiego doby narodowego socjalizmu. Tekst i jego rola postrzegane są tu przez pryzmat wartości w kontekście uniwersalnym, a także, a może przede wszystkim przez pryzmat reprezentowanych w nim językowych środków wartościowania. Jako że wybranym elementom rzeczywistości kreowanej przy pomocy języka zwyczajowo przypisujemy oceny, które nie tylko mają odzwierciedlić nasz stosunek do nich, lecz także nierzadko w sposób implicytny mają zmusić odbiorcę komunikatu językowego do określonej i pożądanej przez emitenta reakcji mentalnej lub fizycznej, nie powinien dziwić fakt, iż język narodowego socjalizmu badany jest tu w perspektywie językoznawczej i socjokulturowej. Łączenie wartości narodowych istotnych dla całej społeczności

https://orcid.org/0000-0002-6652-9068. 
$\mathrm{z}$ oficjalną interpretacją prawdy i nie-prawdy stanowiło $\mathrm{w}$ dobie narodowego socjalizmu priorytet. Pojawia się tu zatem problem interpretacji, nadawania konkretnym zjawiskom czy sytuacjom odpowiednich i jedynie słusznych znaczeń, czyli z punktu widzenia języka wartości problemów związanych z manipulacją i perswazją. Te właśnie mechanizmy i adekwatne językowe środki wartościowania opanowały język niemiecki w dobie narodowego socjalizmu, o czym traktować będzie niniejszy artykuł.

\section{Kontekst badań}

Przyczynkiem do niniejszych rozważań stała się lektura artykułu germanisty okresu narodowego socjalizmu Manfreda Pechau'a pod tytułem „Nationalsozialismus und deutsche Sprache”. Wspomniany artykuł opublikowany został w grudniowym wydaniu teoretycznego organu NSDAP ${ }^{2}$ „Nationalsozialistische Monatshefte” z roku 1937. Dokonany przez autora wybór periodyku, w którym to jego tekst został opublikowany, nie pozostał dziełem przypadku. Założycielem owego organu, powstałego w 1930 roku w Monachium, jak również jego wydawcą był Alfred Rosenberg 3 , czołowy ideolog nazistowski ijeden z najbliższych współpracowników Adolfa Hitlera. Do historii Rosenberg przeszedł jako główny architekt teorii rasistowskich, które umieścił w drugiej ${ }^{4}$ co do znaczenia dla narodowego socjalizmu publikacji „Der Mythus des 20. Jahrhunderts'5 (1930), stanowiącej kompendium jego poglądów na świat i życie,

\footnotetext{
2 NSDAP - wykorzystywany przez władze nazistowskie na szeroką skalę akronim, oznaczający nazwę partii Nationalsozialistische Deutsche Arbeiterpartei (pl.: Narodowosocjalistyczna Niemiecka Partia Robotników), w którym na szczególną uwagę w kontekście niniejszych rozważań zasługują leksemy national-sozialistisch i deutsch, zawierające już w sobie wartościowanie wówczas konotowane jednoznacznie pozytywnie.

3 Alfred Rosenberg redagował także najważniejszą nazistowską opiniotwórczą gazetę „Völkischer Beobachter”, był członkiem NSDAP, posłem do Reichstagu, a także piastował szereg funkcji państwowych, w tym szefa Urzędu Polityki Zagranicznej NSDAP, od 1941 ministra Rzeszy ds. Okupowanych Terytoriów Wschodnich, czy też urząd „Pełnomocnika Führera do spraw duchowego i światopoglądowego wychowania i szkolenia NSDAP” (niem.: Amt des „Beauftragten des Führers für die Überwachung der gesamten geistigen und weltanschaulichen Erziehung der $\left.N S D A P^{\prime}\right)$.

${ }^{4} \mathrm{Z}$ oczywistych względów hierarchicznych zaraz po „Mein Kampf”'Adolfa Hitlera.

${ }^{5}$ Co ciekawe idea owej publikacji oraz jej tytuł nie były dziełem przypadku czy też czystej inwencji twórczej samego autora, gdyż pozycja ta wykoncypowana została jako kontynuacja dzieła niemieckiego pisarza angielskiego pochodzenia Houstona Stewarta Chamberlaina „Die Grundlagen des 19. Jahrhunderts” (1899). To właśnie na podstawie tego dzieła Rosenberg z kolei sformułował własny punkt widzenia na dzieje świata, ze szczególnym naciskiem na dzieje narodu niemieckiego i jego przodków rozpatrywane z nazistowskiego punktu widzenia, a także zaczerpnął podwaliny dla
} 
do których to odnajdujemy $\mathrm{z}$ kolei szereg żywych odniesień $\mathrm{w}$ samym omawianym tekście Pechau'a. Szczególnie relewantnym z punktu widzenia niniejszych rozważań zdaje się także być fakt, iż Manfred Pechau obok swej działalności naukowej i publicystycznej (przez pewien okres pracował bowiem jako dziennikarz m.in. w gazecie uniwersyteckiej), był także silnie zakorzeniony w wyznawanej ideologii w sposób praktyczny i nader aktywny - w roku 1931 wstąpił do SA, gdzie pełnił także funkcję rzecznika prasowego, w roku 1932 został członkiem NSDAP, w 1933 zorganizował w Greifswaldzie akcję palenia książek, w której to też brał czynny udział, a jako SS-Sturmbannführer od roku 1938 kierował w urzędzie, znanym pod skróconą nazwą „Amt Rosenberg” (ARo)', działem Politischer Katholizismus.

Jak zatem wynika z przytoczonych argumentów osoba Alfreda Rosenberga, reprezentowane przez niego poglądy jak również jego spuścizna publicystyczna są nierozerwalnie związane z zawodowymi losami Manfreda Pechau'a i przekładają się W sposób bezpośredni na idee oraz liczne przykłady prezentowane w omawianym tekście. Często cytowane są także wypowiedzi innych czołowych ideologów doby narodowego socjalizmu: obok wspomnianego Alfreda Rosenberga oczywiście Adolfa Hitlera czy Josepha Goebbelsa (patrz m.in.: 4[1060], 5[1061], 6[1062], 15[1071]). Nazwisko tego ostatniego opatrzone jest każdorazowo posiadanym przez niego tytułem naukowym (niem. Dr. Goebbels), co uwiarygodnić ma jego kompetencje, ukazać go jako postać głęboko osadzoną w nauce i tym samym szczególnie predestynowaną do częstego cytowania w pracy naukowej, do miana której pretenduje omawiana publikacja. Sam wymieniany każdorazowo tytuł naukowy przypisać ma jego posiadaczowi wartości naukowe konotowane silnie pozytywnie, a zestawienie $\mathrm{z}$ tak znanym nazwiskiem ma za zadanie zwielokrotnić ten efekt.

swych teorii na temat kwestii żydowskiej i to na nim w końcu oparł szereg własnych publikacji o charakterze czysto antysemickim i rasistowskim.

${ }^{6}$ Termin Amt Rosenberg (ARo) pojawia się w literaturze tematu w wąskim i szerokim znaczeniu. W szerokim znaczeniu tego terminu jest to szereg jednostek/urzędów, którymi Alfred Rosenberg zawiadował w latach 1928-1945, zatem jeszcze w czasie istnienia Republiki Wajmarskiej oraz później $\mathrm{w}$ dobie narodowego socjalizmu. Użyty w niniejszym artykule termin odnosi się zasadniczo do wąskiego znaczenia owego pojęcia i charakteryzuje powstały w 1934 roku urząd do spraw duchowego i światopoglądowego wychowania i szkolenia NSDAP (niem.: Amt für die Überwachung der gesamten geistigen und weltanschaulichen Schulung und Erziehung der NSDAP), na którego czele jako pełnomocnik Führera stanął właśnie Alfred Rosenberg. Z powodu długości oficjalnej nazwy owego urzędu od 1934 roku w powszechnym użyciu pozostawały nazwy skrócone: Reichsüberwachungsamt (Barbian 1995: 276), Überwachungsamt Rosenberg (Brenner 1962: 25), Amt Rosenberg (tamże: 28) czy też Überwachungsamt (tamże: 34). 
Rzeczą sporną wydawać się może fakt, czy określanie Manfreda Pechau’a mianem lingwisty, jak to czyni Gerd Simon (2003) w tytule swej publikacji „NSSprache aus der Innensicht. Der Linguist Pechau und der Massenmord in den Sümpfen bei Loknja“, poświęconej temuż właśnie autorowi, nie jest aby zbyt daleko idącym nadużyciem. Stałoby się to jedynie na podstawie zaledwie jednej jego publikacji - opublikowanej w roku 1935 dysertacji - oraz jednego z założenia naukowego artykułu, powstałego wiernie na jej podbudowie. Wspomniana publikacja dotycząca języka narodowego socjalizmu jest kompilacją głównych tez, które Pechau zawarł w swej rozprawie doktorskiej o tożsamym tytule ${ }^{7}$, na podstawie której w roku 1935 uzyskał on tytuł doktora nauk humanistycznych w uniwersytecie im. Ernsta Moritza Arndta w Greifswaldzie ${ }^{8}$. Autor ten nie prowadził jednak żadnych dalszych badań naukowych z zakresu językoznawstwa i nawet uwzględniając charakter badań językoznawczych prowadzonych przez ówczesnych niemieckich naukowców ${ }^{9}$, a tym samym specyfikę badań prowadzonych przez samego autora, czy wreszcie szeroko rozumiany ówczesny kontekst społeczno-kulturowy, trudno jest współcześnie odnieść się w sposób bezkrytyczny do kwestii kompetencji językoznawczych, jak również jakości wywodu oraz całego dorobku naukowego Pechau'a. Nadmienić przy tym także należy, iż obie prace naznaczone są jednoznacznie piętnem epoki, w której ich autorowi przyszło prezentować wyniki swych naukowych przemyśleń. Jako iż Pechau tworzył w myśl nurtu narodowego socjalizmu i nader skwapliwie prezentował rolę języka niemieckiego w kontekście ideologii nazistowskiej, a tym

\footnotetext{
7 Jak podaje Simon (2003: 4) tytuł „Nationalsozialismus und deutsche Sprache“ zostać miał ustalony już jesienią 1932 roku przez promotora jego rozprawy Wolfganga Stammlera (germanisty, autora słownika pisarzy oraz innych istotnych dzieł językoznawczych), jako temat pracy seminaryjnej, prawdopodobnie jednak już z myślą o późniejszej dysertacji. Ta zostać miała przyznana 10 sierpnia 1934 za zdany z notą "dobry" ("gut") egzamin doktorski przez Pruski Uniwersytet w Greifswaldzie imienia Ernsta Moritza Arndta, a w roku 1935 ukazała się drukiem.

8 Uniwersytet w Greifswaldzie założony został w 1456 roku jako drugi najstarszy uniwersytet w regionie Morza Bałtyckiego. W czasie istnienia III Rzeszy, w maju 1933 roku, otrzymał imię Ernsta Moritza Arndta, byłego profesora z Greifswaldu i delegata do parlamentu we Frankfurcie. Sam wybór patrona uczelni do dziś wzbudza kontrowersje, Jörg Schmidt w niemieckiej opiniotwórczej gazecie Die Zeit (46/1998) nazywa go wprost „patronem fatalnym”, jako iż ów niemiecki literat, głoszący hasła antyfrancuskie i nawołujący obywateli do walki przeciwko okupacji Niemiec przez wojska Napoleona Bonaparte, wykorzystywany był przez propagandę nazistowską jako przykład patrioty, a jednocześnie nacjonalisty i antysemity. Wielokrotnie postulowano zmianę nazwy uczelni - próbę taką bez sukcesu podjęto w roku 2010, natomiast w roku 2017 Senat Uniwersytetu w Greifswaldzie zadecydował co prawda, iż uczelnia nie będzie już dłużej nosiła imienia Ernsta Moritza Arndta, jednak decyzja ta nie została zaakceptowana przez Ministerstwo Oświaty Meklemburgii-Pomorza Przedniego (patrz: Schweriner Volkszeitung 2017).

${ }^{9}$ Więcej na ten temat patrz: Simon (1990); Lerchenmüller/Simon (2009).
} 
samym podkreślał ową znaczącą i w jego mniemaniu wiodącą rolę swego narodu i jego języka dla całej cywilizacji, wspierając tym samym reżim, naukowa wartość owych badań poddawana jest w wątpliwość.

Najdobitniej na temat walorów naukowych dysertacji Manfreda Pechau'a wypowiedzieli się Lerchenmüller/Simon (2009: 93) stwierdzając w sposób wysoce wartościujący, jakoby miała być ona niczym więcej, jak tylko wypracowaniem szkolnym, skleconym naprędce i byle jak w niedzielne popołudnie („ein am Sonntag Nachmittag hingeschluderter Schulaufsatz'). Dodatkowych informacji dostarcza druga część cytowanego wcześniej tytułu - zestawienie osoby Pechau’a z masowym mordem implikuje jego udział w tymże wydarzeniu i wartościuje tym samym, niosąc konotację jednoznacznie negatywną. Simon w swojej publikacji opisał ową „naukową” sferę działalności Manfreda Pechaua, jednak znaczną ilość miejsca poświęcił także jego pozanaukowej aktywności, nazywając Pechau’a wprost zbrodniarzem wojennym. Wszystkie te zabiegi deprecjonują osobę omawianego autora, a co za tym idzie umniejszają rolę jego ewentualnego dorobku naukowego.

Niezależnie jednak od kwalifikacji samego autora tekstu, to właśnie opisywany przez niego język narodowego socjalizmu, a ściślej rzecz biorąc sama kwintesencja narodowego socjalizmu przedstawiona w relacji do języka (tu: niemieckiego) i dla pełniejszego osadzenia w ramach naukowych zilustrowana frazami głoszonymi przez jego głównych ideologów, stanowią główny punkt zainteresowania dla dalszych rozważań niniejszej publikacji.

\section{Podstawy teoretyczne i stan badań}

\subsection{Język narodowego socjalizmu w świetle debaty naukowej}

Zanim zagłębimy się $\mathrm{w}$ analizę języka narodowego socjalizmu i towarzyszących mu aspektów językoznawczych i socjokulturowych należy sobie zadać fundamentalne w tym kontekście pytanie: Czy zjawisko, które określamy mianem „języka narodowego socjalizmu” w ogóle istnieje, czy jest to jedynie pewne uproszczenie, stworzone na potrzeby debaty i krytyki społecznej? Na tak postawione pytanie stara się także odpowiedzieć Senya Muller (1994: 25), prezentując $\mathrm{w}$ porządku chronologicznym podejścia naukowców do tego zagadnienia. Mimo, iż wielu z nich zdaje się odrzucać zdecydowanie ideę istnienia takiego konstruktu jak ,język narodowego socjalizmu” (niem. NS-Sprache), argumentując, iż wiele cech zauważalnych w owym języku można upatrywać w języku niemieckim także przed rokiem 1933 i jako takie nie mogą być one zatem cechami dystynktywnymi wyłącznie języka doby narodowego socjalizmu, 
to jednak termin ten pojawia się dość konsekwentnie $\mathrm{w}$ opracowaniach dotyczących języka niemieckiego tego okresu. Na bardziej adekwatne określenie sytuacji języka doby narodowego socjalizmu w Niemczech pomiędzy rokiem 1933 i 1945 badacze proponują szereg innych pojęć: LTI ${ }^{10}$ (Klemperer 1947), Sprache des Dritten Reiches, Nazi-Deutsch (Paechter, 1944), Vokabular des Nationalsozialismus (Berning, 1964), Wortschatz eines Unmenschen (Sternberg/Storz/Süskind, 1967), Sprachwandel im Dritten Reich (Seidel-Slotty, 1961).

Dlatego też w dalszej części publikacji na określenie języka doby narodowego socjalizmu w Niemczech w latach 1933-1945 posługiwać się będę pojęciem język narodowego socjalizmu jako pewnym uogólnieniem, rozpatrując ten fenomen $\mathrm{w}$ jego najbardziej charakterystycznej warstwie, to jest w płaszczyźnie leksykalnej, uwzględniając przy analizie tekstu semantykę leksykalną i zabarwienie stylistyczne oraz wzbogacając ją o aspekt socjokulturowy, decydujący $\mathrm{w}$ tym przypadku o ostatecznym wydźwięku i charakterze oddziaływania na ówczesnego odbiorcę.

\title{
3.2. Puryzm językowy w Niemczech
}

W tradycji niemieckiej bardzo silne zakorzeniona jest dbałość o czystość języka. Puryzm językowy w Niemczech rozkwitał ze szczególną siłą w wieku XIX i pierwszych dziesięcioleciach wieku XX. Język miał być gwarantem narodowości, zatem wszelkie elementy obce mogły tej jakże istotnej wartości zagrozić. Jak pisze Lipczuk (2003: 141):

\begin{abstract}
Silne wpływy innych języków na język niemiecki sprawiły, iż często dochodziło do negatywnych reakcji: pojawiały się - mniej lub bardziej uzasadnione - głosy, iż język niemiecki zalewany jest cudzoziemszczyzną, co stanowi niebezpieczeństwo dla tożsamości języka i narodu. Właśnie motywy narodowe (język jest gwarantem narodowości) dominują $\mathrm{w}$ historii walki z wyrazami pochodzenia obcego w języku niemieckim.
\end{abstract}

Niemiecki tradycyjny puryzm językowy (niem.: Deutscher Sprachpurismus), walcząc o utrzymanie tak rozumianej przez siebie „niemieckości”, wymierzony był przeciwko dawnej wyższości kulturowej łaciny, greki czy też języka francuskiego

\footnotetext{
${ }^{10}$ LTI - Lingua Tertii Imperii, czyli Język Trzeciej Rzeszy - skrótowiec, pochodzący z tytułu książki Victora Klemperera: LTI. Notizbuch eines Philologen, Berlin: Aufbau-Verlag, 1947, będącej studium semantycznym języka ówczesnych Niemiec. Jest to przewrotna gra słów, będąca ironicznym nawiązaniem do powszechnie stosowanych przez władze nazistowskie akronimów niem.: NSDAP, KDF, HJ. BDM itp.
} 
(por. Klemm 2005). Jednak w okresie narodowego socjalizmu radykalnie zmienił on swe oblicze i przeszedł od postawy językowej charakteryzującej się przesadną dbałością o czystość języka, głównie w kontekście wyrazów pochodzenia obcego, aż do postawy o charakterze silnie rasistowskim, a ściślej rzecz biorąc przyjął on cechy antysemickie. Już w latach 30-tych zaczęto wznosić w kontekście czystości języka zdecydowane postulaty antysemickie, nawołujące do tzw. „Aufnordung”11 języka niemieckiego poprzez, jak głosił to ówczesny działacz na rzecz dbałości o język ojczysty profesor Ewald Geissler, walkę z „tamtym językiem niemieckim, który był utajnionym językiem żydowskim" (tamże; tłumaczenie własne - KKŻ).

W takim też tonie odnośnie zagadnień związanych z kwestiami językowymi wypowiadał się Manfred Pechau. W celu głębszego osadzenia w wyznawanej ideologii oraz nadania swym twierdzeniom naukowego szlifu autor opierał się na znamienitych, jego zdaniem, autorytetach naukowych, germanistach, badaczach historii języka, leksykografach, a jednocześnie wiodących ideologach systemu. W kontekście czystości językowej oraz obecności wyrazów pochodzenia obcego w języku niemieckim Pechau odwołuje się więc w swej pracy do przekonań Joachima Heinricha Campego (1746-1818), niemieckiego pisarza, pedagoga i leksykografa. Cytowany przez autora Campe (1937: 2[1058]) pisze: „Ohne Reinheit der Sprache ... findet keine allgemeine Belehrung, keine Volksaufklärung oder Volksausbildung in irgendeinem beträchtlichen Grade der Allgemeinheit, statt”. Czystość języka winna mieć zatem znaczenie kluczowe, jako iż to ona właśnie determinuje oświecenie czy kształcenie narodowe, bez niej to wreszcie nie może być mowy o jakimkolwiek procesie edukacji powszechnej ${ }^{12}$.

\footnotetext{
${ }^{11} \mathrm{Pl}$. Nordyzacja, lub też aryzacja - termin oznaczający w narodowo-socjalistycznej nomenklaturze proces, polegający na wzroście potencjału nordyckiego w społeczeństwie, tu: narodzie, a pozwalający się z niego pozbyć elementów niepożądanych i zbędnych - nie-nordyckich. Termin Aufnordung pojawia się niejednokrotnie w pracach Hansa Friedricha Karla Günthera, niemieckiego językoznawcy i badacza ras, który przywiązuje do niego najwyższą wagę w kontekście państwowości i narodu: „Die Aufgabe der Aufartung kann der Staat übernehmen; die Aufgabe der Aufnordung kann in Deutschland und Österreich nur durch Selbsthilfe der nordischen Rasse, durch Zusammenschluß der nordisch-gesinnten Deutschen, gelöst werden; denn es ist klar, daß der Staat sonderrassische Bestrebungen nicht zu den seinen machen kann.“ (1934: 136). Jako zatem że pojęcie rasy w narodzie obejmowało w głównej mierze kwestię „krwi” (niem. Blut), aspekt ten w narodowosocjalistycznej nordyzacji był wiodący. Franz Rosenzweig twierdził nawet, iż mowa to coś więcej niż krew („Sprache ist mehr als Blut"). W kolejnym planie zatem Aufnordung łączyło się także z aspektem językowym, czyli tzw. germanizacją językową (niem. sprachliche Germanisierung), czyli zjawiskami, do których odnosi się także niniejsza publikacja.

12 Co ciekawe wspomniany cytat umieszczony został w pracy Pechau’a w wersji okrojonej: „Ohne Reinheit der Sprache, d.i. ohne eine für ein ganzes Volk verständliche, also durch ihre eigene Ähnlichkeitsregel begrenzte, und alles Fremde, dieser Ähnlichkeitsregel widerstrebende,
} 
Cytowany jest też Friedrich Ludwig Jahn (1778-1852), publicysta narodowościowy, twórca ruchu gimnastycznego - turnerskiego (od niem. turnen), który przystosował koncepcję fizycznej edukacji młodzieży do poglądów nacjonalistycznych i dzięki temu, w mniemaniu Pechau'a, niejako wyprzedzając swą epokę daleko dogłębniej poświęć się miał rozważaniom na temat sytuacji w Niemczech, niż inni mu współcześni. Jahn dowodził: „Naród, który zatraca swój własny język, traci swe prawo głosu w obrębie ludzkości i skazany jest na odgrywanie niemej roli na scenie narodów" (por. Pechau 1937: 2[1058], tłum. Własne - KKŻ), by zaraz potem dodać „Język jest wędrówką duszy narodu”, co Pechau uznał za szczególnie istotne i w czym upatrywał tzw. politische Ausrichtung. Termin ten używany był w nomenklaturze tego okresu nader często i chętnie - sam Pechau odnosi się do niego wielokrotnie (o czym mowa w dalszej części niniejszej publikacji) i umiejscawia go nawet dwukrotnie w pierwszym zdaniu swego artykułu, odnosząc się zarówno do orientacji politycznej „niemieckiego człowieka” jak i narodowo-socjalistycznego kierunku „działalności naukowej".

\subsection{Wartościowanie i prawda w kontekście narodowego socjalizmu i języka}

W kontekście dalszych rozważań zasadniczą rolę odgrywa zjawisko wartościowania i jego rola w tekście. Szczepaniak (2017: 59) za Kellerem przedstawia wartościowanie $\mathrm{w}$ ogólnym rozumieniu jako operację mentalną, względnie mentalno-emocjonalną (lub zbiór operacji mentalnych), „której efektem jest przyjęcie postawy akceptacji lub odrzucenia w odniesieniu do danego obiektu - osoby, przedmiotu, miejsca lub procesu - w oparciu o określone kryteria lub oczekiwania normatywne (najczęściej presuponowane)". Podobnie Puzynina (1992: 83) wskazuje na procesy psychiczne, które stanowią punkt wyjścia dla wartościowania, zauważając, iż: „wartościowanie to zasadniczo czynność psychiczna człowieka polegająca na stwierdzeniu, jakie (i w jakim stopniu) wartości pozytywne lub negatywne [...] właściwe są - zdaniem osoby wartościującej - danym cechom, zachowaniom, stanom rzeczy, a pośrednio przedmiotom”. W tym kontekście podkreślić zatem należy zarówno podmiotowość samego procesu wartościowania, odnoszącą się do osoby wartościującej, jak i z drugiej strony jego przedmiotowość - coś lub ktoś podlega owemu wartościowaniu, stając się jego przedmiotem.

Wartościowanie opiera się na przypisaniu danemu desygnatowi określonych wartości, które w oczach samego wartościującego można lub też należy mu

ausschließende Sprache findet keine allgemeine Belehrung, keine Volksaufklärung oder Volksausbildung, in irgend einem beträchtlichen Grade der Allgemeinheit, Statt" (Campe (1813) VI). 
przypisać. Szczepaniak (2017: 59) podkreśla fakt, iż wartościowanie wykazuje społeczny charakter, co w efekcie pozwala na odróżnienie go od „osądu smaku”, który będąc oceną deskryptywną nie implikuje ani racjonalnej dyskusji, ani żadnego uzasadnienia, co wynika z faktu, iż „kryteria prawdziwości pozostają znane tylko osobie ją formułującej, nie mają charakteru intersubiektywnego".

Wartościowanie wykazuje bezpośredni związek z perswazją, co widać szczególnie wyraźnie na przykładzie komunikacji politycznej. Każda władza, a w szczególności systemy totalitarne, w imię zachowania swej tożsamości i zamanifestowania odrębności dąży do kształtowania wspólnoty narodowej, stara się podeprzeć te dążenia ideologicznie, a następnie w sposób eksplicytny lub implicytnie poprzez manipulację stara się narzucić swym członkom swe subiektywne koncepcje prawdy i nie-prawdy, odpowiadające jej swoistym potrzebom. Jako spoiwo ideologiczne wykorzystywany jest także język. Naród scala zatem nie tylko jego własna religia, tradycja, system wierzeń i wartości, w tym naszkicowanym szerszym kontekście percepcji prawdy, lecz także język, pozwalający na pragmatyczne wyartykułowanie wszelakich myśli i idei. Wspomniana koncepcja prawdy dostosowana jest do aktualnych potrzeb scalania narodu, a w opozycji do niej funkcjonuje nie-prawda ${ }^{13}$, która dla wzmocnienia semantycznego nazywana jest fałszem. Nie-prawda zdaje się być jedynie prawdą w sposób formalny poprzedzoną partykułą nie, zatem jej negacją, przez co moc słowa i siła wyrazu w jego pierwotnym znaczeniu zostały znacznie osłabione. Fałsz natomiast posiada zdecydowanie silniejszą moc znaczeniową, wywołując silne konotacje wartościujące jednoznacznie negatywnie.

W kontekście niniejszych rozważań warto także zauważyć za Puzyniną (2014: 10), iż z jednej strony ważne są dla nas samych wartości pojęte egocentrycznie, „interesownie”, z drugiej jednak strony interesują nas wartości istotne dla całych społeczności ludzkich, a głębszej refleksji wymagałby fakt, $\mathrm{w}$ jakim stopniu te pierwsze $\mathrm{i}$ te drugie stanowią przedmiot naszego zainteresowania. Łączenie wartości narodowych, tych właśnie relewantnych dla całej społeczności, z oficjalną interpretacją prawdy i nie-prawdy stanowiło $\mathrm{w}$ dobie narodowego socjalizmu priorytet. To, co prawdziwe, postrzegano jako wartość samą w sobie - pozytywne lub negatywne w swym przekazie, jednak odpowiadające realnym narodowym potrzebom takiej właśnie a nie innej interpretacji. To, czego nie określano mianem prawdziwego, obwoływane było kłamstwem, jednoznacznie i bez możliwości jakiegokolwiek sprzeciwu. Wszelki

13 Celowo używam takiej pisowni, traktując ją jako rodzaj stylizacji, by także wizualnie podkreślić ową formą udział prawdy w nie-prawdzie oraz podkreślić różnicę semantyczną i uwypuklić siłę wartościowania w odniesieniu do leksemu „fałsz”. 
fałsz zatem uderzał bezpośrednio w naród i jako taki stanowić miał silne zagrożenie dla jego egzystencji. Pojawia się tu zatem problem interpretacji, nadawania konkretnym zjawiskom czy sytuacjom odpowiednich i jedynie słusznych znaczeń, czyli z punktu widzenia języka wartości, jak pisze Puzynina (2014: 8), problemów związanych z manipulacją i kłamstwem. Oba te zjawiska Puzynina interpretuje jako wprowadzanie ludzi w błąd, przy czym dodaje, iż w wypadku manipulacji dzieje się to dla jakichś zamierzonych korzyści manipulującego, w wypadku kłamstw natomiast nie zawsze musi to nastąpić, gdyż istnieją tzw. „białe kłamstwa”. W interesujących nas kwestiach związanych z polityką, prowadzoną i propagowaną przez ideologów nazizmu, zauważyć można dalej za Puzyniną, iż danym postawom, zachowaniom, sytuacjom, wydarzeniom, osobom czy też instytucjom za pomocą manipulacji i kłamstwa przypisuje się zazwyczaj wartości pozytywne lub negatywne, niezgodne z rzeczywistością, jednak odpowiadające reprezentowanej przez wartościującego linii politycznej.

Jeśli wszelki fałsz, kłamstwo i nieuczciwość względem założeń ideologii nazistowskiej uderzać miał bezpośrednio w państwo, a co za tym idzie w utożsamiany z nim naród i jako taki stanowił zagrożenie dla jego egzystencji, należało go jednoznacznie potępić i napiętnować, jako wartość negatywną. Pod pojęciem narodu skrywał się tu jednak termin silnie nadużyty przez ideologów narodowego socjalizmu i volkizmu ${ }^{14}$. Naród to już nie tylko trwale uformowana wspólnota ludzi, określana przez swoją kulturę i historię, powstała na tle wspólnych instytucji polityczno-państwowych oraz posiadająca poczucie świadomości i więzi grupowej (por. Grabarczyk, 2003: 55), lecz także panteistyczna mistyka „krwi i ziemi” (Blut und Boden), łącząca propagowaną przez niemiecki folkizm doktrynę o istnieniu narodów predestynowanych z paranaukowym dyskursem o rzekomym występowaniu ras ludzkich wyższych i niższych. Fichte (1808: 252) mówił zatem o „pranarodzie” (Urfolk), Hegel (1820: 143 ${ }^{15}$ ) o „duchu narodu” (Volksgeist), czy wreszcie Heidegger (1944: 30) o Niemcach jako o narodzie poetów i myślicieli (Volk des Dichtens und Denkens).

\footnotetext{
14 Volkizm, także: niemiecki folkizm (pisownia spolszczona), (niem. völkischer Nationalismus, stanowiący rasistowską bazę światopoglądową dla völkische Bewegung) - termin etymologicznie wywodzący się od niemieckiego słowa das Volk (tu: naród) i określający specyficzną rasistowską myśl ideologiczną, pokrewną nacjonalizmowi, charakteryzującą się pseudonaukowym neoromantycznym i irracjonalnym charakterem, znacznym mistycyzmem, łączeniem wyjątkowych cech narodowych z krajobrazem, w jakim naród ukształtował się u swego zarania, jego wartościowanymi pozytywnie cechami oraz ideą narodów predestynowanych.

${ }^{15}$ Hegel w swej publikacji z 1820 roku pt.: „Grundlinien der Philosophie des Rechts“ po raz pierwszy napomina o terminie Volksgeist w $\S 156$ na stronie 143: „(...) der wirkliche Geist einer Familie und eines Volks".
} 
Grabarczyk (2003: 55) cytując „doniosłe” stwierdzenie Herdera, iż język określa ludzi mówiących tym samym językiem, odnosi się także do potwierdzającego je Humboldta, który w aspekcie powiązania języka z duchowym bytem stwierdza: "Język jest jednocześnie zewnętrzną formą ducha narodów, ich język jest ich duchem, a ich duch właśnie ich językiem" (Humboldt 1843: 229, cytat za Grabarczyk 2003: 55). Humboldtowska wizja narodu jako języka w sposób jednoznaczny łączy zatem te pojęcia - zaznaczając ścisłą korelację także pomiędzy sposobem myślenia i poglądami tegoż narodu, dowodząc jednocześnie, iż działalność danego narodu związana jest z użyciem języka - dlatego niemożliwym zdaje się istnienie jednego bez drugiego (Humboldt 1843: 112, cytat za Grabarczyk 2003: 58). Nie dziwi w tym kontekście fakt, iż to właśnie owemu terminowi Volk $\mathrm{w}$ relacji do języka tak wiele uwagi poświecił w swej publikacji także Manfred Pechau.

\section{Językowe środki wartościowania $\mathrm{w}$ tekście $\mathrm{w}$ aspekcie językoznawczym i socjokulturowym}

Wartościowanie realizuje się $\mathrm{w}$ tekście za pomocą językowych środków wartościowania i rozpatrywać je można na różnych płaszczyznach. Jak jednak zauważa Puzynina (1992: 118) „Podstawowym środkiem językowym służącym wyrażaniu wartości są słowa”. To właśnie warstwa leksykalna stanowi punkt odniesienia dla dalszych analiz zawartych w niniejszej publikacji.

\subsection{Wartościowanie $\mathrm{w}$ języku w myśl idei narodowych}

Pechau przekonuje o istotnej, a wręcz wiodącej roli języka w funkcjonowaniu całego narodu i w związku z tym w sposób szczególny zajmuje się tematyką „Wort- und Sprachforschung” (1937: 2[1058]), które to badania rozumie jednak nie jako prywatne błahostki (Privatspielereı), a w sposób znacznie szerszy, jako swego rodzaju ideę ogólnonarodową. Nie badanie zatem dążeń poszczególnych użytkowników języka, którzy podejmowali próby wywierania na niego wpływu, wzbogacając go lub oczyszczając, winno stać w centrum badań językoznawcy, a odpowiadanie potrzebom całego narodu. Praca językoznawcy musi więc oddawać tzw. marszowy krok narodu (niem. Marschtritt des Volkes), który to krok jakże ufnie winien odzwierciedlać język (por. Pechau 1937: 2[1059]). Termin Volk w kontekście narodu pojawia się zresztą w omawianym tekście wielokrotnie. Istotę nośności tegoż terminu wyjaśnia w obrazowy sposób Drozdowicz (2010: 49):

Pojęcie ludu (das Volk) i zrozumienie jego ideologicznego zabarwienia jest w tym ujęciu problemem kluczowym. Lud rozumiany w tradycji niemieckiej zarówno jako 
grupa społeczna, jak i ogół społeczeństwa (naród) jest w pierwszej kolejności identyfikowany nie tyle ze wspólnotą ideową, co ze swoistym braterstwem krwi (wspólnotą biologiczną), konceptualizowanym społecznie poprzez kulturową metaforę wielkiej „rodziny” wszystkich Niemców.

Pechau zatem korzystając z owego produktywnego i wartościującego pozytywnie leksemu Volk po wielokroć odnosi się do wspomnianej wyżej narodowej wspólnoty ideowej, wymieniając chociażby takie złożenia jak: Volksmarsch (1937: 2[1058]), Volksbewegung (3[1059]), Volksgenosse, Volkskanzler, Volksführer, Volksgeist, Volksstimme, Volksbuch, Volksreligion, Volkssprache (4[1060]) itp. W celu uzyskania ponownie efektu wartościowania nacechowanego pozytywnie Pechau wywodzi złożenia z członem Volk (tu: Wortbildungen mit „Volk”) „najczęściej” z wcześniejszych epok (1937: 4[1060]), co ma pseudonaukowo zwielokrotnić ich wartość i powołując się na uznane przez siebie autorytety naukowe podaje najcenniejsze ich przykłady, m.in.: Herder - Volksgenosse (1798), Volksseele (1769), Volkslied (1771), Campe - Volksführer, Volkslenker, Volksregierung, Volksreligion, Volksbewegung, Volksbuch, Volksspiel. Tu, aby odnieść się do współczesnych mu czasów i zachować odpowiednie politische Ausrichtung autor buduje analogie i przedstawia oczywiste w jego mniemaniu złożenia Volkskanzler - jako określenie Adolfa Hitlera, czy Volksbuch vom Hitler - jako znamienej książki autorstwa Hitlera, uwypuklając w ten sposób ich szlachetną, jego zdaniem, etymologię i ubierając je w szatę wartościującą wyjątkowo pozytywnie. Zwielokrotnieniu pozytywnej siły wartościowania ma służyć także zestawienie $\mathrm{w}$ prezentowanych złożeniach dwóch denotatów o znacznej sile

W interesujący sposób Pechau odnosi się do złożenia Volkspolitik (1937: 4[1060]), które jakoby miało być po raz pierwszy użyte w roku 1859 przez Ferdinanda Lassalle (1825-1864), jako hasło (Schlagwort) wymierzone przeciw książętom i uznaje je dość wstrzemięźliwie za przykład pouczający, pomimo, iż jego autorstwo przypisuje myślicielowi niemieckiemu pochodzenia żydowskiego (tu wartościując już bardziej jednoznacznie negatywnie, jako: von dem Juden Lassalle). By jednak nie doszukiwać się $\mathrm{w}$ tym stwierdzeniu zbytniej pochwały autor dodaje niezwłocznie, iż przykład jest interesujący, jednakże ukazuje on, jak Żydzi odwoływać się mieli do narodu, określając się jego przewodnikami (Volksführer), w celu zabezpieczenia swoich wpływów politycznych. Cel został zatem osiągnięty: pozytywna wartość leksemu Volk zachowana, a pierwotny autor złożenia i cała ideologia stojąca za omawianym terminem odpowiednio zdeprecjonowana, poprzez użycie jednostki leksykalnej niosącej konotację silnie 
negatywną Jude oraz partykuły doch - przeciwstawiającej pozytywny Volk z negatywnymi nadużyciami jego eksploatacji podpartej interesami Juden.

\section{2. „Nowe słowa” w nomenklaturze narodowo-socjalistycznej}

Choć sam Pechau podkreśla, iż istotą jego pracy nie jest zarejestrowanie nowych słów, lecz skłonienie odbiorcy do przemyśleń nad istotą tego, co mają nam one do przekazania (por. 1937: 3[1059]), lektura jego publikacji zdaje się nieść jednak zgoła inne przesłanie - być może nawet wbrew pierwotnej idei autora. Recypient bowiem wcale nie musi zagłębiać się $\mathrm{w}$ rozważania nad danym przekazem słownym, gdyż robi to za niego sam autor, narzucając mu niejako ,jedynie słuszną interpretację". Chcąc osiągnąć taki efekt Pechau naszpikował swój tekst jednostkami podkreślającymi jednoznacznie intencje autora i nieuznającymi sprzeciwu, jak: selbstverständlich, klar, deutlich, stosuje styl imperatywny, wyrażany szczególnie obrazowo poprzez nadużywanie czasownika modalnego müssen, zdania wykrzyknikowe czy wreszcie przekazywane $\mathrm{w}$ tekście wprost instrukcje postępowania, np.:

(...) Deshalb ist selbstverständlich, wer nicht den richtigen Tritt des Volksmarsches hat, für den heißt es 'Tritt gewechselt'. Wer das Kommando nicht versteht, der muß nachexerzieren, bis er es gelernt hat. (Pechau 1937: 2[1058] - podkreślenia w tekście własne KKZ).

Pod stosowanym przez niego określeniem owych wspomnianych wyżej „nowych słów" kryją się licznie cytowane za ich autorami jednostki, nieco szersze frazy czy wreszcie poszczególne wypowiedzi, zawierające $\mathrm{z}$ reguły różnego rodzaju skrajne sformułowania (zarówno inwektywy, jak i frazy jednoznacznie nobilitujące), wyrażane za pomocą językowych środków wartościowania, zasadniczo realizowane $\mathrm{w}$ tekście na poziomie warstwy leksykalnej, niekiedy okraszone komentarzem na temat ich wartości semantycznej lub ukazujące określone zabarwienie stylistycznie. Pod nazwą „nowych słów” zatem w nomenklaturze narodowo-socjalistycznej w tekście Pechau’a kryją się nie tylko i wyłącznie neologizmy (lub też rzadziej ze względu na ograniczenia w ich zrozumieniu okazjonalizmy), to wszelkie jednostki w szerokim tego słowa znaczeniu, niosące nowe, narodowosocjalistyczne przesłanie i mające moc silnie wartościującą. Do głównych językowych środków wartościowania w tekście należą tu m.in. jednostki leksykalne wartościujące pozytywnie lub negatywnie (o zabarwieniu i sile zależnej od omawianych aktualnie kwestii ideologicznych), neologizmy, słowa sztandarowe (Fahnenwörter), hasła i slogany, (Schlagwörter), epitety, metafory czy porównania. Wśród kryteriów tekstowości wyróżnia się tu 
jednoznacznie intencjonalność, wskazująca na podążanie autora $\mathrm{z}$ nurtem rozwijającej się ideologii nazistowskiej, intertekstualność, jako że tekst wykazuje bardzo silne powiązania $\mathrm{z}$ innymi tekstami o podobnym nacechowaniu propagandowym - m.in. „Mein Kampf”, „Der Mythus des 20. Jahrhunderts”, czy też zebrane przemowy Goebbelsa - oraz sytuacyjność powstałego tekstu, który silnie oddziaływać miał na odbiorcę w zaistniałej wówczas sytuacji społecznopolitycznej.

Rozważania dotyczące wartości formacji słownych odnoszących się do ruchu nazistowskiego (Wortbildungen der Bewegung) Pechau rozpoczyna od analizy samej nazwy owego ruchu, czyli terminu Nationalsozialismus (por. 1937: 3[1059]), który uważa za fundamentalny dla nomenklatury narodowo-socjalistycznej i wywodzi go od Rudolfa Riellena (1910).

Jednym $\mathrm{z}$ obecnych także $\mathrm{w}$ omawianym tekście sposobów wartościowania jest nadużywana, także w tekstach nie-fachowych, (pseudo)terminologia fachowa - mająca na celu nadanie wypowiedziom pozornie naukowej wiarygodności. W omawianym tekście Pechau'a pojawiają się zatem cytowane nowo utworzone jednostki, w przeważającej mierze z zakresu retoryki politycznej, takie jak np.: Novemberrevolte (6[1062]), Futterkrippenpolitik (7[1063]), Nadelstichpolitik, Gesinnungsakrobaten (8[1064]) czy Tributzeppelin (9[1065]), wykazujące jednocześnie znamiona jednostek sfrazeologizowanych. Obok złożeń jako nowe słowa pojawiają się $\mathrm{w}$ tekście liczne kolokacje z zakresu retoryki politycznej: preußischer Sozialismus (4[1060]), parlamentarische Maulwürfe (6[1062]) oraz odniesienia religijne: politische Methusalems (8[1064]), koschere Ausbeutungsanstalt (9[1065]), verorientalisierter Christentum (14[1070]). Wartościując omawiane zagadnienia jednostki te pełnią $\mathrm{w}$ tekście funkcję moralizatorską, a także perswazyjną, co odbiorca odczytać winien zgodnie z intencją nadawcy (por. Kukowicz-Żarska 2010: 137). Kontekst użycia danej jednostki frazeologicznej odwoływać się może do jego prymarnego, oczywistego dla szerokiego grona odbiorców znaczenia, jednakże w sytuacji, gdy nie jest on typowy, skłaniać może do sięgnięcia do zasobów wiedzy ogólnej recypienta (por. Kukowicz-Żarska 2010: 136). Jako że funkcja moralizatorska i perswazyjna omawianych "nowych słów” wysuwa się w nomenklaturze narodowosocjalistycznej na plan pierwszy, odbiorca nierzadko zmuszony jest czerpać właśnie z owej wiedzy ogólnej. Najważniejszym zadaniem danej jednostki nie są jednak zagadnienia czysto semantyczne czy też zawiłe zagadnienia etymologiczne. W centrum uwagi znajduje się tu finalny odbiór danego złożenia czy kolokacji w kontekście wartościowania, gdyż recypient ma zgodnie z zamysłem autora skoncentrować się głównie na przekazie propagandowym. 


\subsection{Militaryzacja języka w aspekcie wartościowania}

Militaryzacja języka, czyli (pseudo)terminologia fachowa $\mathrm{z}$ zakresu języka wojskowości są $\mathrm{w}$ tekście wszchobecne. Znamienne są już pierwsze zdania publikacji:

"Wir sprechen viel von politischer Ausrichtung des deutschen Menschen, auch von politischer Ausrichtung des wissenschaftlichen Arbeiters. Die Notwendigkeit dieser Ausrichtung wird auf vielen Gebieten aber ungern anerkannt. Und doch ist der gleiche Marschtritt die primitivste Voraussetzung für das Vorwärtskommen einer geschlossenen Truppe. Deshalb ist selbstverständlich, wer nicht den richtigen Tritt des Volksmarsches hat, für den heißt es 'Tritt gewechselt'. Wer das Kommando nicht versteht, der muß nachexerzieren, bis er es gelernt hat. Das ist einfache Tatsache in der Wissenschaft so selbstverständlich wie beim Militär." (Pechau 1936: 2[1059]).

Zaczerpnięty z języka wojskowości czasownik ausrichten był bardzo produktywny - w powyższym cytacie pojawia się aż trzykrotnie $\mathrm{w}$ formie rzeczownika odczasownikowego Ausrichtung, charakteryzował się nader wysoką częstotliwością użycia i jako taki występował zwyczajowo w większości tekstów pisanych, jak również w przemówieniach, wygłaszanych przez prominentnych działaczy tego okresu. Odnosił się on do nigdy niekończącego się zadania, jakim jest nadawanie procesom myślenia i odczuwania narodu całkowicie jednolitego narodowosocjalistycznego kierunku (por. Schmitz-Berning, 1998). Poprzedzony przymiotnikiem politisch stworzył $\mathrm{w}$ nomenklaturze narodowego socjalizmu termin politische Ausrichtung, mający nadać wypowiedziom pozory naukowej wiarygodności i odnosząc się zarówno do myśli politycznej „obywatela niemieckiego” jak i ukierunkowania politycznego „działalności naukowej” mającym stanowić określenie dla wyznawanej koncepcji politycznej czy też obowiązującego politycznego punktu widzenia.

W kontekście języka narodowego socjalizmu częste są także wojskowe odniesienia, zdające się być wręcz jego integralną częścią - tylko w cytowanym powyżej fragmencie tekstu Pechau'a odnajdujemy ich cały szereg: Militär, Truppe, Marschtritt, Volksmarsch, Kommando, Tritt - a to tylko nieliczne z określeń tego typu używanych na szeroką skalę w tekstach ideologów tej epoki. W dalszej części publikacji Pechau'a pojawia się nawet rozdział zatytułowany „Kampfsprachformen”, w którym autor zajmuje się językiem określonym przez siebie jako Kampfsprache (język walki), czyli słowami, jakimi naznaczona jest walka, którą prowadzi narodowy socjalizm przeciwko „systemowi” (por. Pechau 1937: 5[1061]). Tu ponownie rozpatrywana jest warstwa leksykalna, co ciekawe 
jednak semantyka słów czy fraz ukazana została w aspekcie historycznym i socjokulturowym, co służyć ma także celom wartościowania. Większość leksemów tu proponowanych wywodzi się jednak nie z języka wojskowości, a z języka debaty politycznej, gdyż język walki autor rozumie jako wspomnianą walkę $\mathrm{w}$ imię narodowego socjalizmu, a nie posługiwanie się słownictwem wywodzącym się z samej tej walki.

Także kolory stanowić mogą podstawę słowotwórczą dla złożeń i stałych związków wyrazowych (Wortbildungen) z zakresu języka wojskowości. Do takich kolorów zaliczyć można przymiotnik braun (brązowy, choć w tym kontekście: brunatny), który jako określający barwę mundurów stanowi dla autora częstą podstawę słowotwórczą i prowadzi do stworzenia takich fraz jak: die Braunhemden, braunes Heer, braunes Ehrenlied, braune Sturmkolonnen, Braunhemdenbeer (Pechau 1937: 4-5[1060-1061]). Wszelkie formacje słowne, tworzone w oparciu o leksem braun, konotowały zdecydowanie pozytywnie, gdyż wywodziły się one od koloru oficjalnego umundurowania SA, czyli bojówek Sturmabteilungen der NSDAP (pol. Oddziały Szturmowe NSDAP), które znane były potocznie jako Braunhemden czyli w języku polskim jako „brunatne koszule". Pod wpływem retoryki nazistowskiej termin ten uległ personifikacji i określano nim już nie samo umundurowanie, które zyskując cechy ludzkie stawało się zdecydowanie częściej podstawą do określania wspomnianych członków owych bojówek.

\subsection{Stałe zwyczajowe zwroty grzecznościowe i ich wymiar społeczny}

Jako formę powitania najczęściej spotykaną w zwyczajowej praktyce społecznej Pechau wymienia pozdrowienie „Heil Hitler“ (1937: 5[1061]). Autor podkreśla przy tym, iż pozdrowienie to powstało rzeczywiście $\mathrm{w}$ samym narodzie, co implicytnie zwiększyć ma jego pozytywną siłę oddziaływania. Dodając następnie, iż jeszcze w roku 1923 głosy aprobaty i zachwytu wahały się naprzemiennie pomiędzy pozdrowieniami „Heil Hitler“ a „Heil Ludendorff“, by jednak ostatecznie w roku 1923 uznać tzw. Hitlergruß za oficjalną formę pozdrowienia, autor wykazuje wyższość tej formy nad jakąkolwiek inną. Dodatkową wyższość tej frazy podkreślać ma także fakt, iż zdaniem autora także i inne partie próbowały naśladować owo powitanie, np. „die Deutschnationalen“ mieli używać pozdrowienia „Heil Hugenberg“, a bliżej nieokreśleni „inni“ (andere) natomiast „Heil Deutschland“. Pechau zaznacza także, iż nie wolno zapomnieć, jakoby obok różnych form pozdrowień („Front Heil“ czy „Frei Heil“) przed kilkoma laty w Niemczech wykrzykiwane także być miało „Heil Moskau“, co stanowi niewątpliwe nawiązanie do formy witania się zwolenników komunizmu. 
Co ciekawe autor ukazując wzorowanie się tej grupy na oficjalnym Hitlergruß wzmacnia siłę oddziaływania tego ostatniego, a użyta forma czasu przeszłego implikuje definitywne zakończenie problemu ze wspomnianym przeciwnikiem. $\mathrm{W}$ podobnie negatywnym tonie autor informuje o akcji katolickiej w tym zakresie, która miała już po przejęciu władzy przez narodowych socjalistów dążyć do przełamania jedności niemieckiego powitania, poprzez próbę wprowadzenia do użycia „Treu Heil“ (Pechau 1937: 5[1061]). Negatywny wydźwięk tych informacji oraz potępiającą nutę podkreśla fakt, iż dojść do tego miało już po zagarnięciu władzy przez Hitlera (Machtergreifung16), a zatem było to działanie godzące $\mathrm{w}$ interes państwa i tym samym wymierzone przeciwko całemu narodowi niemieckiemu.

Żadnego wyjaśnienia natomiast nie wymaga, zdaniem autora, wzrost znaczenia i szacunku, jakim obdarzane jest powszechnie słowo Führer (wódz) oraz pochodząca od niego forma zwracania się (Anrede) brzmiąca "Mein Führer" (Pechau 1937: 5[1061]). Komentarz dla istoty tego typu zwrotów zdaje się autorowi zbędny, gdyż traktuje go jak reszta społeczeństwa z namaszczeniem i fakt takiego uwznioślenia owych wypowiadanych słów jest dla niego nader oczywisty. Jednak nawet dzisiejszemu odbiorcy elenemty te w całej krasie ukazują ówczesną polityczną moc wartościowania o wydźwięku pozytywnym, społeczne uwielbienie i pełną akceptację, stanowiąc tym samym kwintesencję narodowego socjalizmu.

\subsection{Wyrazy obcego pochodzenia jako „zagrożenie dla języka“}

W kwestii obecności wyrazów pochodzenia obcego w języku niemieckim Pechau argumentuje, iż istota niemieckości oddana być może jedynie przy pomocy rodzimych słów. Jako autorytet $\mathrm{w}$ tej kwestii służy mu ponownie postać niemieckiego leksykografa Campego, który jako twórca pierwszego znaczącego słownika wyrazów obcych (w 5 tomach, 1807-1811), a także tzw. słownika zniemczającego (Verdeutschungswörterbuch) (1801, potem 1813) starał się konsekwentnie zastępować wyrazy pochodzenia obcego wyrazami rodzimymi, np.: Kultur - Geistesanbau, Apparat - Gerätschaftssammlung, Individuum -

16 Co ciekawe, termin Machtergreifung (pol. zagarnięcie władzy; w literaturze też jako Machtübernahme - przejęcie władzy) przez ówczesnych użytkowników języka niemieckiego - z oczywistych względów zwolenników idei narodowo-socjalistycznych - konotowany był niezwykle pozytywnie, jako obraz siły i konsekwencji w dążeniach - odzwierciedlenie wydarzenia dotyczącego dokonanego 30 stycznia 1933 objęcia władzy rządowej w Niemczech przez NSDAP i zaprzysiężenia Adolfa Hitlera przez prezydenta Paula von Hindenburga jako Kanclerza Rzeszy. Dzień ten ustanowiono świętem narodowym, w którym dumnie obchodzono powstanie III Rzeszy. Współcześnie pod wpływem idących za tym wydarzeń historycznych określenie to, co oczywiste, nacechowane jest jednoznacznie negatywnie. 
Einzelwesen, Universität - Hochschule itd. Autor czynił to argumentując, iż wyrazy obce są dla prostego odbiorcy niezrozumiałe i dlatego winno się je zastępować słowami o strukturze przejrzystej i bardziej zrozumiałej. Kierować się zatem Campe miał ideami oświeceniowymi, nie zaś typowymi dla wcześniej omawianego puryzmu niemieckiego ideałami narodowymi (por. Lipczuk 2003: 140). Jednak Pechau traktuje niemieckiego leksykografa jako autorytet w zakresie obchodzenia się wyrazami pochodzenia obcego w języku i opierając się ponownie na jego przekonaniach widzi niebezpieczeństwo w fakcie, iż wyrazy te stać się mogą inherentnym elementem języka niemieckiego, co ilustruje przykładem słowa Religion i obszernym cytatem ze "Słownika języka niemieckiego" („Wörterbuch der Deutschen Sprache”)" ${ }^{17}$, którego autorem jest właśnie Campe (Pechau 1937: 16[1072]). Autor twierdzi, jakoby brak tak znaczącego i prawdziwie niemieckiego słowa dla niewłaściwej obcej religii miał być jedną $\mathrm{z}$ głównych przeszkód tak znacznie utrudniających i opóźniających powszechne oświecenie, albowiem właśnie to obce słowo zdaje się być jednym z tych, które uniemożliwiają osobie nieuczonej odnalezienie jakichkolwiek głębszych znaczeń, a jedynie pozwala natknąć się na te pozbawione głębszego sensu, z którymi winien on skojarzyć koncepcję myśli uniwersalnej, nie zmysłowej. W tym kontekście właśnie to słowo, pozbawione $\mathrm{w}$ mniemaniu owego nieuczonego odbiorcy wszelkiej zmysłowości, zdaje się nie oferować mu żadnych odniesień czy konotacji. Pechau dalej cytując Campego (1801: 12-13) nawiązuje do jego dalszego stwierdzenia, jakoby tak wielki wpływ czystości języka z jednej strony i jego nieczystości z drugiej oddziaływać miał znacząco na naród, na jego sposób myślenia, a przez to na stan moralny całego narodu - co jakoby utrzymywać się może przez całe tysiąclecia. Wspomniane powyżej słowo religia potwierdzać ma też spostrzeżenie, że obce słowa zawierające nonsensowne pojęcia nigdy nie powinny przenikać do języka narodowego, a jeśli już to proces ten przebiegać winien bardzo powoli.

\subsection{Unifikacja społeczeństwa vs. deprecjonowanie przeciwnika}

Narodowy socjalizm jako ideologia skrajna, oparta na fundamentach szowinistycznych i rasistowskich reprezentując dyskurs perswazyjny opierała się na prostej, jednakże bardzo obrazowej i przemawiającej do wyobraźni recypienta

\footnotetext{
${ }^{17}$ Pechau podaje w przypisie 6 na stronie 16[1072], iż wspomniany fragment cytuje za Campe 1807 czyli jakoby czerpie go ze słownika jezyka niemieckiego („Wörterbuch der Deutschen Sprache”), wydanego w roku 1807 w Braunschweig. Cytat ten jednak odnaleźć można na wskazanych przez niego stronach 12-13 nie w podanej pozycji, a we wspomnianym powyżej tzw. słowniku zniemczającym „Wörterbuch für Erklärung und Verdeutschung der unserer Sprache aufgedrungenen fremden Ausdrücke”, wydanym pierwotnie w 1801, a następnie w 1813 roku.
} 
dychotomii myślenia ${ }^{18}$ my (= ci dobrzy) i oni (= ci źli). Za Ruth Wodak (2008: 186) warto także nadmienić, iż cała komunikacja w sferze politycznej zawsze wiązać się będzie z istnieniem rozróżnienia owego typu opozycji „my” vs. „oni” czy też „swój” vs. „obcy”, a to z kolei pociąga za sobą konieczność stworzenia adekwatnego wizerunku emitenta: pozytywnie konotowanego wizerunku tych „naszych” oraz negatywnej charakterystyki tych „obcych”. W tym celu retoryka narodowo-socjalistyczna wykorzystywała słownictwo patetyczne, odwołując się do dumy narodowej, a także budowała pewną wspólnotę - unifikując społeczeństwo, czyli naród, do czego twórcy tej retoryki w obrazowy sposób używali zaimka osobowego w pierwszej osobie liczby mnogiej my. Jednocześnie w myśl tego zabiegu deprecjonowano przeciwnika (onı), przeciwstawiając ową grupę zunifikowanej i wartościowanej pozytywnie wspólnocie własnej. Cała sfera wartościowania $\mathrm{w}$ omawianym tekście sprowadzona jest zatem zgodnie z oczekiwaniami do owej stereotypowej opozycji - my, którzy mówimy prawdę, niesiemy ją na sztandarach i głosimy na chwałę narodu, oraz oni, „ci inni”, którzy mając poglądy odmienne od naszych nie mogą opierać ich na prawdzie, ergo kłamią. Ten jeden $\mathrm{z}$ podstawowych mechanizmów perswazji pozwala autorowi $\mathrm{w}$ prosty i zrozumiały sposób wartościować, przypisując pozytywne cechy zbiorowości „my”, a wszelkie negatywne grupie „oni”. „Nasze” poglądy zatem jako wartościujące pozytywnie są jedynie słuszne, prawdziwe i godne naśladowania, „ich” natomiast są fałszem, nikczemnym kłamstwem, które jako takie stanowiło opozycję do prawdy, konotowaną jednoznacznie negatywnie. Jako iż wartościowanie wiąże się tu $\mathrm{w}$ sposób bezpośredni z ideałami, wyznawanymi przez samego autora tekstu, a także tezami głoszonymi oficjalnie przez NSDAP, traktować je można jako uzupełnienie propagandowej linii partii i realizowanie perswazyjnej funkcji języka (por. Walczak, 1994: 20), jako odpowiadające hasłom głoszonym przez wyznawców tego nurtu ideologicznego, a co za tym idzie jako jedynie właściwe.

\subsection{Tło społeczno-kulturowe jako źródło wartościowania}

Leksemami o zabarwieniu negatywnym autor zajął się w swej publikacji m.in. we fragmencie zatytułowanym „Die Revolution vom November 1918” (Pechau 1937: 6 [1062]). Termin ten, by podkreślić jego wagę, wyróżniony został wizualnie na tle reszty tekstu poprzez wyśrodkowanie i pełni w tym fragmencie tekstu dwojaką rolę: jednocześnie stanowi tytuł fragmentu (podrozdziału) oraz jest częścią zdania rozpoczynającego ów fragment - jego podmiotem. W świetle nakreślonych już

18 Lub też: myślenia dychotomicznego - rodzaj błędu procesów myślowych (wyróżniony przez Aarona Becka), odznaczający się postrzeganiem wszelakich zjawisk jedynie w aspektach skrajnych. 
wcześniej intencji przyświecających autorowi publikacji nie powinien dziwić fakt, iż już samo przywołanie tytułowej nazwy rewolucji listopadowej 1918 roku, stanowiące dla ówczesnych odbiorców nie tylko termin historyczny, lecz także silne hasło propagandowe o szerokim odbiorze społecznym, niesie ze sobą określoną konotację - konotację czysto negatywną. Użycie terminu Die Revolution vom November 1918 nie jest tu przypadkowe i służy określonym celom. Już w owym pierwszym zdaniu następuje dodatkowe podkreślenie negatywnego wydźwięku tego terminu poprzez porównanie go do konotowanej zdecydowanie negatywnie rewolty (niem. Revolte). Autor czyni to, jak twierdzi, po to, by oddać charakter owego „nikczemnego spisku” (por. Pechau 1937: 6 [1062]), jakim miała być właśnie rewolucja listopadowa 1918 roku. By cały ów nikczemny charakter spisku zaprezentować odbiorcy w pełnej krasie, autor przygotował ucztę semantyczną, popartą znamienitymi w jego mniemaniu autorytetami (Hitler, Goebbels, Jung, Hecker). W całym fragmencie zaprezentowana została zatem szeroka gama złożeń, powstałych na bazie nazwy miesiąca - jak podaje autor paralelnie do innych już funkcjonujących, np. Julirevolution czy Märzrevolution), np.: Novemberrevolte, Novemberverbrecher, Novemberlumpen, Novemberpropheten. Wszystkie te złożenia mają podwójną moc wartościującą - z jednej wzbudzonej poprzez użycie jednostek ewaluacyjnych wartościujących jednoznacznie negatywnie (Revolte, Verbrecher, Lumpen), z drugiej zaś strony zwielokrotnioną poprzez użycie leksemu „November”, także wzbudzającego u ówczesnego odbiorcy, zaznajomionego z kontekstem społecznopolitycznym, skojarzenia negatywne - jako tego odnoszącego się do oczywistych w swym wydźwięku i ocenianych negatywnie wydarzeń listopadowych. Z owym listopadem właśnie oraz listopadowymi zbrodniarzami (Novemberverbrecher) związana była tzw. Dolchstoßlegende, czyli legenda o ciosie w plecy, której wartościujący wydźwięk ilustruje wyraziście poniższa karykatura: 


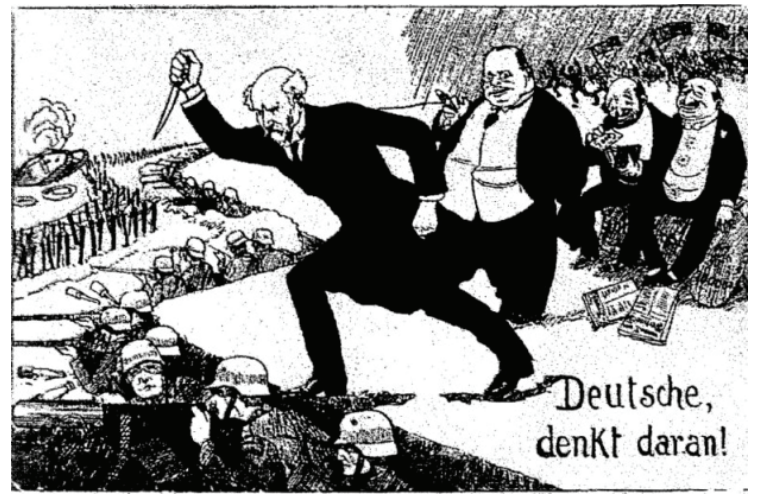

Rys. 1. "Deutsche, denkt daran!" - historyczna karykatura na karcie pocztowej dotycząca niemieckiej propagandowej „legendy o ciosie w plecy” (niem. Dolchstoßlegende) ${ }^{19}$

Już samo wykorzystanie we wspomnianym złożeniu leksemu „legenda” jest zdecydowanym semantycznym nadużyciem. Legenda w kontekście literackim jako opowieść o dawnych bohaterach rozbudza ciekawość, wyzwala konotacje pozytywne i ma dla danej społeczności silną wartość emocjonalną i scalającą. Wspomniana powyżej legenda o ciosie w plecy nie ma jednak na celu gloryfikacji bohaterów w niej ukazanych oraz ich heroicznych czynów, lecz wręcz przeciwnie - stanowi rodzaj populistycznej teorii spiskowej, jaka pojawiła się w Niemczech po roku 1918. Służyła ona celom jednoznacznie propagandowym, a jej źródeł należy upatrywać w głoszonych wówczas populistycznych hasłach, obarczających winą za przegraną I wojnę światową ówczesny socjaldemokratyczny rząd Friedricha Eberta $^{20}$, który podpisał kończący wojnę rozejm w Compiègne. Omawiana karykatura zaopatrzona została w imperatywne wezwanie do narodu niemieckiego „Deutsche, denkt daran!”, określające jednoznacznie jako krąg odbiorców całe społeczeństwo niemieckie (Deutsche) oraz mające na celu zwrócenie uwagi na ilustrowane $\mathrm{w}$ tak negatywny sposób wydarzenie i namawiające do głębszej refleksji na ten temat (denkt daran) - użycie wykrzyknika implikuje właściwie nakaz takiego potraktowania tematu.

19 Źródło: http://www.bpb.de/geschichte/deutsche-geschichte/ersterweltkrieg/155331/das-ende-deskaiserreichs [dostęp 12.11.2018].

${ }^{20}$ Friedrich Ebert (1871-1925) niemiecki polityk, socjaldemokrata, lider Socjaldemokratycznej Partii Niemiec (SPD), w latach 1919-1925 prezydent Niemiec. Nieprzyjazne nastawienie do niego wzmógł fakt, iż był on sygnatariuszem traktatu wersalskiego z ramienia Niemiec i jako taki obarczony został odpowiedzialnością za jego postanowienia, mimo, że zdecydowanie opowiadał się przeciw oddaniu części ziem Polsce (Pomorza, Śląska i Poznańskiego). Podczas wojny polsko-bolszewickiej proklamował neutralność Niemiec, co wymierzone być miało przeciwko Polsce, gdyż uniemożliwiało tranzyt przez tereny niemieckie i dotarcie w ten sposób do Polski pomocy z zachodu. 
Tak jak cytowane w tekście Pechau'a określenie Dolchstoß - Dolchstoßleute (1937: 6[1062]) czy Dolchstoßjournaille (1937: 11[1066]) zakłada znajomość ówczesnej sytuacji i nastrojów społecznych, tak karykatura, która się do niego odnosi zakłada znajomość przez ówczesnego odbiorcę wyglądu zewnętrznego uczestników owych wydarzeń. Na pierwszym planie karykatury bowiem przedstawiono Philippa Scheidemanna ${ }^{21}$, wznoszącego nóż i wbijającego go w plecy nadal dzielnie walczącej armii niemieckiej, oraz Matthiasa Erzbergera ${ }^{22}$, stojącego za jego plecami i przyglądającego się temu atakowi z aprobatą i ze stoickim spokojem. Od roku 1918 wszelkich polityków niemieckich biorących udział $\mathrm{w}$ pracach negocjacyjnych dotyczącej kapitulacji Niemiec postrzegano $\mathrm{w}$ tym kraju jako zdrajców narodu, tzw. listopadowych zbrodniarzy i postępowanie ich oceniano szczególnie surowo. Nasiliło się to zdecydowanie w dobie narodowego socjalizmu, gdy propaganda stała się dla przeciwników porządku weimarskiego szczególnie ważnym narzędziem w dążeniu do zagarnięcia pełni władzy. Termin listopadowi zbrodniarze nabrał wówczas jeszcze większej mocy. Historyk i wicedyrektor ds. naukowych Niemieckiego Instytutu Kultury Polskiej Peter Oliver Loew (2017) w swojej publikacji na łamach portalu internetowego Forum Dialogu ${ }^{23}$ napisał:

Krążyło negatywne określenie "listopadowi zbrodniarze" - o tych wszystkich "lewicowcach" i "demokratach", którzy rzekomo podstępnie zdradzili dzielną,

${ }^{21}$ Philipp Scheidemann (1865-1939) niemiecki polityk, mąż stanu, socjaldemokrata, członek partii SPD, deputowany do Reichstagu, od 1919 także kanclerz, a właściwie premier Rzeszy (niem. Reichsministerpräsident). Jako jeden z twórców Republiki Weimarskiej, (którą proklamował 9 listopada 1918 z balkonu Reichstagu, wbrew woli ówczesnego kanclerza Friedricha Eberta), stał się przedmiotem ataków propagandowych narodowych socjalistów, mimo iż jako Premier Rzeszy był zdecydowanym krytykiem kończącego I wojnę światową traktatu wersalskiego, który odrzucił, podając się następnie wraz ze swym gabinetem do dymisji.

${ }^{22}$ Matthias Erzberger (1875-1921) niemiecki polityk, pisarz, w roku 1918 jako pełnomocnik Rządu Rzeszy (Reichsregierung) oraz przewodniczący komisji ds. zawieszenia broni prowadził negocjacje dot. zawieszenia broni pomiędzy Ententą a Niemcami oraz podpisał układ rozejmowy w Compiègne. Po wojnie piastował stanowisko Ministra Rzeszy ds. Finansów (Reichsminister der Finanzen), zreformował i ujednolicił niemiecki system podatkowy. Zamordowany w 1921 roku przez prawicową terrorystyczną Organizację Consul (niem. Organisation Consul, O.C.), której gro członków zasiliło po utworzeniu w 1921 roku szeregi SA - Oddziałów Szturmowych NSDAP (niem. $S A$ - Sturmabteilung, Die Sturmabteilungen der NSDAP).

${ }^{23}$ FORUM DIALOGU - Perspektywy ze środka Europy to portal internetowy, zajmujący się w sposób publicystyczny kwestiami powiązanymi z politycznym i kulturowym wymiarem Europy. W centrum zainteresowania znajdują się relacje między Niemcami i Polakami na płaszczyźnie politycznej, kulturowej i historycznej. Portal jako projekt Federalnego Związku Towarzystw Niemiecko-Polskich współpracuje także z Polsko-Niemieckim Magazynem DIALOG oraz z gdańskim czasopismem Przegląd Polityczny (Źródło: https://forumdialogu.eu/onas/ [dostęp 12.11.2017]). 
niezwyciężoną armię. W ten sposób 11 listopada coraz bardziej nabierał charakteru negatywnego miejsca pamięci narodu, stawał się symbolem narodowej hańby, za którą przyjdzie jeszcze kiedyś wziąć odwet i która w końcu - jak naziści chętnie zwodzili - wydawała się być przezwyciężona z dniem 30 stycznia 1933 roku.

Pechau ponownie nie zawodzi w kwestii ukazania pełnego wachlarza jednostek wartościujących negatywnie, mianem których obdarzano właśnie owych listopadowych zbrodniarzy, od wspomnianych już powyżej określeń przypisywanych Hitlerowi: Novemberverbrecher, Novemberlumpen, Novemberpropheten, poprzez zdaniem autora znane już od czasów „Rewolucji 1848"24 roku Umsturzmänner, na Dolchstoßleute oraz fremde Söldlinge (tu termin Söldlinge - najemnicy wzmocniony negatywnie poprzez użycie przymiotnika fremd - obcy, ukazujący wpływy zewnętrzne) skończywszy. Złożenie Novemberpropheten (listopadowi prorocy) bez znajomości realiów ówczesnej epoki i nastrojów społecznych zdawałoby się być wartościującym pozytywnie, jednak autor spieszy z rozwianiem choćby najmniejszej wątpliwości na ten temat, dodając, iż odnosić się ona ma do „kłamliwych proroctw” rewolucyjnych sępów (niem. Revolutionsgeier) (Pechau 1937: 6[1062]). Tak więc wydźwięk także i tego złożenia nie pozostawia wątpliwości.

Do wyjątkowo istotnych jednostek, stanowiących szczególne dobro narodowe w zakresie języka, Pechau zalicza złożenia, w których jako człon wówczas wartościujący jednoznacznie pozytywnie występuje nazwisko Führera, a jako najbardziej znaczące wymienia Hitlerjugend (Pechau 1937: 5[1061]). Są to złożenia uznawane ogólnospołecznie za takie i obdarzane w narodzie szczególnym szacunkiem pod wpływem wyznawanej ideologii. Co ciekawe autor nadmienia $\mathrm{w}$ tym miejscu również, iż $\mathrm{w}$ czasie walki [o władzę] $\mathrm{w}$ obozie przeciwników narodowego socjalizmu także wykorzystywano szereg określeń z tymże członem, którymi latami z lubością „karmiła się” wroga propaganda i które wartościuje negatywnie wprost nazywając "głupimi słowami” (por. tamże) - Hitlersumpf, Hitlerbonze, Hitlergeneral, Hitlerbaron. O ile jednostki Sumpf ('bagno') czy Bonze ('bonza', 'aparatczyk' lub 'wyniosły urzędnik, urzędas']) posiadają zrozumiałe również dla współczesnego recypienta znaczenie wartościujące jednoznacznie negatywnie, o tyle General czy Baron w tych złożeniach konotują już negatywnie

24 Pod nazwą tą autor rozumie tzw. Niemiecką rewolucje 1948/1949 (niem. Deutsche Revolution 1848/49), zwaną także Rewolucją marcową 1848 (niem. Märzrevolution 1948), czyli zryw rewolucyjny w początkach Wiosny Ludów, mający miejsce pomiędzy marcem 1848 a lipcem 1849 roku, obejmujący zakresem swego oddziaływania terytorium Związku Niemieckiego (niem. Deutscher Bund) i przejawiający się licznymi demonstracjami i wystąpieniami mieszkańców, domagających się wolności politycznej oraz zjednoczenia państw niemieckich w jeden kraj. 
pod warunkiem znajomości ówczesnych realiów. Także użycie czasownika speisen (tu w języku debaty politycznej w pejoratywnym znaczeniu 'karmić, żywić kogoś czymś', 'karmić, żywić się czymś', 'być pożywką dla kogoś, czegoś') w kontekście takiego doboru wartościujących fraz jak: „wroga propaganda”, „przeciwko narodowemu socjalizmowi”, „obóz przeciwników”, wzmacnia implicytnie negatywną moc wartościowania w tymże zdaniu.

\section{Uwagi końcowe}

Elementy wartościujące w tekście Manfreda Pechau’a stanowią podstawę przemyśleń autora i obejmują zdecydowaną większość prezentowanego materiału leksykalnego. Cytowane frazy odnoszą się w dużej mierze do wzorców literackich, kulturowych czy historycznych, i jako takie wypełniają swą propagandową misję nadrzędną. Strategie językowe wspierające funkcję perswazyją, z których korzysta w swojej publikacji autor, realizują przekaz wartościujący o nacechowaniu pozytywnym - w odniesieniu do zwolenników narodowego socjalizmu, oraz negatywnym - w kontekście jakiejkolwiek opozycji do propagowanych idei. Za Wodak (2008: 195-196) strategie te scharakteryzować można jako systematycznie powtarzające się sposoby użycia języka, określone w sposób mniej lub bardziej szczegółowy i świadomie przyjęte jako działania komunikacyjne, w których za pomocą odpowiednio dobranych środków językowych emitent zmierza w najbardziej efektywny sposób do osiągnięcia zamierzonych przez siebie celów - społecznych, politycznych czy też psychologicznych. Takie rozumienie omawianych zachowań komunikacyjnych odnieść można w sposób oczywisty do języka narodowego socjalizmu, dla którego stanowi ono klamrę spajającą przedstawione powyżej analizy materiału leksykalnego.

\section{Bibliografia}

Barbian, Jan-Pieter (1995). Literaturpolitik im »Dritten Reich». Institutionen, Kompetenzen, Betätigungsfelder. Nördlingen: De Gruyter.

Brenner, Hildegard (1962). „Die Kunst im politischen Machtkampf 1933/34.“ [w:] Vierteljahrshefte für Zeitgeschichte. 10/1962, zeszyt 1, s. 17-42.

Campe, Joachim Heinrich (1813). Wörterbuch zur Erklärung und Verdeutschung der unserer Sprache aufgedrungenen fremden Ausdrücke. 2. Aufl., Braunschweig.

Drozdowicz, Jarema (2010). Nazistowski okultyzm a niemiecka koncepcja narodu i wspólnoty. [w:] Przegląd Religioznawczy, 2010, nr 1 (235), s. 47-57.

Fichte, Johann Gottlieb (1808). Reden an die deutsche Nation. Berlin: Realschulbuchhandlung.

Grabarczyk, Zenon (2003). Język ojczysty a naród. [w:] Acta Neophilologica, V, 2003, Olsztyn: UWM Olsztyn, s. 55-66. 
Günther, Hans F. K. (1934). Kleine Rassenkunde des deutschen Volkes. München: J.F. Lehmanns Verlag.

Hegel, Georg Wilhelm Friedrich (1820). Grundlinien der Philosophie des Rechts Naturrecht und Staatswissenschaft im Grundrisse. Zum Gebrauch für seine Vorlesungen. [w:] Grotsch, Klaus/Weisser-Lohamnn, Elisabeth (red.) Gesammelte Werke, Bd. 14.1, Hamburg. 2009.

Heidegger, Martin (1944). „Heimkunft/An die Verwandten.“ [w:] von Herrmann, Friedrich-Wilhelm (red.) Gesamtausgabe. 1. Abteilung: Veröffentlichte Schriften 1910-1976. Bd. 4. Erläuterungen zu Hölderlins Dichtung. Frankfurt a. M.: Klostermann. 1981.

Klemm, Michael (2005). „Wenn die Sorre in Gilbhart durch die Zeugemutter fährt... Kleine Geschichte der sprachpflegerischen Eindeutschungen - von erfolgreich bis skurril“. [w:]: LEO. Lingua et Opinio. Studentische Zeitschrift zu Sprache und Kommunikation. 22 Februar 2005.

Kukowicz-Żarska, Katarzyna (2010). „Funkcje związków frazeologicznych w tekstach doniesień prasy sportowej.“ [w:] Linguistica Bidgostiana. Vol. VII, Bydgoszcz: Wydawnictwo Uniwersytetu Kazimierza Wielkiego, s. 133-144.

Makowski, Jacek (2003). Zur Sprache im Nationalsozialismus. Forschungsbericht. [w: ] Lingua ac communitas, 13/2003, s. 61-72.

Lerchenmüller, Joachim/ Simon, Gerd (2009). Im Vorfeld des Massenmords. Germanistik und Nachbarfächer im 2. Weltkrieg. Eine Übersicht. Tübingen: GIFT Gesellschaft für interdisziplinäre Forschung Tübingen.

Lipczuk, Ryszard (2003). „Puryzm językowy w Niemczech - historia i teraźniejszość.” [w:] Bulletin de la Société Polonaise de Linguistique, fasc. LIX, s. 140-149.

Pechau, Manfred (1937). „Nationalsozialismus und deutsche Sprache.“ [w:] Nationalsozialistische Monatshefte. Zentrale politische und kulturelle Zeitschrift der NSDAP. Heft 93, Dezember 1937. München: Zentralverlag der NSDAP, s. 2-16 [1058-1072].

Puzynina, Jadwiga (2014). Kłopoty $\mathrm{z}$ nazwami wartości (i wartościami). [w:] Etnolingwistyka 26, Lublin, s. 7-20.

Puzynina, Jadwiga (1992). Język wartości. Warszawa: PWN.

Szczepaniak, Jacek (2017). Wartościowanie jako praktyka komunikacyjna (na przykładzie tekstów prasowych z dziedziny gospodarki i ekonomii). [w:] LingVaria: Półrocznik Wydziału Polonistyki UJ poświęcony zagadnieniom języka i językoznawstwa. Tom 12 Nr 24 (2017), s. 57-69.

Walczak, Bogdan (1994). „Co to jest język polityki?” [w:] Anusiewicz, Janusz/ Siciński, Bogdan (red.). Język a Kultura. T. 11. Wrocław, s. 15-20.

Wodak, Ruth (2008). Dyskurs populistyczny: retoryka wykluczenia a gatunki języka pisanego. W: A. Duszak, N. Fairclough, red.: Krytyczna Analiza Dyskursu. Interdyscyplinarne podejście do komunikacji społecznej. Kraków: Towarzystwo Autorów i Wydawców Prac Naukowych UNIVERSITAS, s. 185-213. 


\section{Netografia}

Loew, Peter Oliver (2017). „11 listopada 1918 w Niemczech i w Polsce - Światło i cień na przyszłość." [w:] Forum Dialogu - Perspektywy ze środka Europy z dn. 13/11/2017. Wersja online: https://forumdialogu.eu/2017/11/13/11-listopada-1918-w-niemczechi-w-polsce-swiatlo-i-cien-na-przyszlosc/ [dostęp 01.12.2018].

Schmidt, Jörg (1998). „Fataler Patron.“ [w:] Die Zeit (46/1998), 02.11.1998. s. 94. Wersja online: die Zeit-Online: http://www.zeit.de/zeitlaeufte/fataler_patron/komplettansicht [dostęp 12.10.2018].

Simon, Gerd (2003): „NS-Sprache aus der Innensicht. Der Linguist Pechau und der Massenmord in den Sümpfen bei Loknja." [w:] Ureland, Sture (red.): Convergence und Divergence of European Languages. (Studies in Eurolinguistics 1). Berlin: Logos. s. 277-303. Wersja online: http://homepages.uni-tuebingen.de/gerd.simon/pechau.pdf [dostęp 12.10.2018].

Simon, Gerd (1990): Der Krieg als Krönung der Wissenschaft. Schwerpunkt. Sprachwissenschaften. Teil I. Wersja online: https://homepages.uni-tuebingen.de/ gerd.simon/KrakrI.pdf [dostęp 12.10.2018]. 